\title{
Hybrid Rice Technology: An Overview
}

\author{
Ehsan Shakiba ${ }^{1 *}$ and Robert C Scott ${ }^{2}$ \\ 1,2Division of Agriculture, University of Arkansas, USA
}

*Corresponding author: Ehsan Shakiba, Assistant Professor, University of Arkansas, Rice Research and Extension Center, 2900 Address: 2900 highway 130 East Stuttgart, AR 72160, USA.

To Cite This Article: Ehsan Shakiba. Hybrid Rice Technology: An Overview. Am J Biomed Sci \& Res. 2019 - 5(1). AJBSR.MS.ID.000865. DOI: 10.34297/ AJBSR.2019.05.000865

Received: 䟧August 28, 2019; Published: 眥 August 30, 2019

\begin{abstract}
Hybrid rice is one of the important innovations in agriculture along with the discovery of the semi-dwarf gene as well as the green revolution. Since releasing the first hybrid rice cultivar in China, the production of hybrid rice has grown rapidly in all world rice growing regions. Developing high yield hybrid rice cultivars with acceptable quality depends on the agronomic characteristics of their parents. This review discusses about the importance of the hybrid rice, methods for developing hybrid rice and their parents, and genes/QTLs associated with desirable agronomic traits.

Keywords: Hybrid Rice; Cytoplasmic male sterile; Environmental genic male sterile; Photoperiod genic male sterile; Temperature genic male sterile; Maintainer line; Restorer Line

Abbreviations: CMS: Cytoplasmic Male Sterile; EGMS: Environmental Genic Male Sterile; PGMS: Photoperiod Genic Male Sterile; TGMS: Temperature Genic Male Sterile; B: Maintainer line; R: Restorer Line; M: Million; ha: Hectar
\end{abstract}

\section{Introduction}

Hybrid rice has proven to be an effective way to enhance rice production. It is defined as commercially grown rice from F1 seeds resulting from a cross between two genetically diverse parents. The advantages of hybrid rice over conventional rice cultivars include better grain yield (up to 15\%) and higher durable resistance to biotic and abiotic factor. These advantages are due to a phenomenon known as heterosis [1]. The first hybrid cultivar, which produced more than $20 \%$ yield over the conventional rice cultivars of that time, was released in China in 1974 [2]. Then, the International Rice Research Institute (IRRI) made an effort to improve hybrid cultivars by developing superior hybrid parental lines. As a result, several commercial hybrid cultivars developed by the IRRI were released in India, Vietnam, the Philippines, Bangladesh, and Indonesia. The major hybrid rice producer in the world are as follows: China, 18.6 Million (M)h that is more than $63 \%$ total of rice area (TRA), India 1.5Mha (3.3\%TRA), Bangeladesh 7.35 Mha (6.5\% TRA), Vietnam, 6.45 Mha (8.7\% TRA), the Philippines, 3.46 Mha (7.8\% TRA), Indonesia $6.2 \mathrm{M}$ ha (0.4\% TRA) ha in USA, 5,000 ha in and 5,000 ha in Myanmar [3].

RiceTec Inc. was granted exclusive access to the hybrid parental lines, including Cytoplasmic Male Sterile (CMS) and Environmental Genic Male sterile (EGMS) lines applied for two-line and three- line systems, respectively, from the Chinese National Hybrid Rice Research Center at Changsha Hunan. In addition, restorer lines were originated from South China INDICA sources that are frequently used as parental lines to develop new restorer lines developed by IRRI. In 2006, RiceTec Inc. developed and released the first hybrid cultivar, XL6, rice for commercial production in the United States. However, XL6 was not successful due to high lodging and poor milling quality. Two years later, RiceTec Inc. released two other hybrid rice cultivars named XL7 and XL8, both of which showed less lodging and better milling quality than XL6 [4]. In 2018, Louisiana State University releases hybrid cultivar, LAH169 that demonstrated a good quality and low chalk [5].

\section{Hybrid Rice Production Systems}

Large-scale production of hybrid seeds is made possible via male sterile lines, which are developed to serve as the female parents. Two types of male sterility are utilized for F1 hybrid production in rice: Three-line system and Two-line system 6 . The first hybrid rice cultivar released in China was developed via the three-line system 2,6 . This system requires three lines of cytoplasmic male sterile (CMS), maintainer (B), and restorer (R) lines. The CMS line is assigned as the female and the $\mathrm{R}$ line is used as the male parent. The sterility in CMS lines is caused by an interaction between genetic factors in the nucleus and mitochondrial genes in the cytoplasm [6].

Several sources of CMS have been identified. However, only 11 CMS sources are used for commercial purposes worldwide, including CMS-WA, CMS-DA, CMP-IP, CMS-DI, CMS- HL, CMS-KR, CMS-BT, CMS-TN, CMS-GAM, CMS-ARC, and CMS. O. perennis 6. These CMS 
sources were discovered in different rice genotypes from the East and Southeast Asia. In CMS-WA, the cytoplasmic source of sterility was derived from a weedy ( 0 . Sativa f. spontanea) rice with abortive pollen and the nuclear donor was the rice line "Zhen Shan 97". In CMS-DA, the cytoplasmic source originated from a dwarf plant of 0 . Sativa $\mathrm{f}$. spontanea, and the nuclear source was donated from the rice line "Xue Qin Zhao". In CMS-IP, the cytoplasm originated from an Indonesian paddy rice and the nuclear donor was the rice line "II-32". In CMS-DI, the cytoplasmic source was the rice line "Dissi type", and nuclear genes originated from the rice line "297". In CMS$\mathrm{HL}$, the source of cytoplasmic sterility originated from 0 . Sativa f. spontanea, and nuclear genes from the rice line "Lian-Tang-Zao". In CMS-KR, the cytoplasmic source of sterility was derived from wild rice Oryza rufipogon, and nuclear donor was cultivar "Taichung 65". In CMS-BT, the cytoplasm originated from the rice line "Chinsurah Boro II", and the nuclear genes were donated from rice line Taichung 65. In CMS-TN, the source of cytoplasmic sterility was derived from rice line "Taichung N1", and the nuclear genes originated from rice "Pankhari 203". In CMS-GAM, the source of cytoplasmic sterility originated from "Gambiaca", and the nuclear donor was "Chao Yang 1". In CMS-ARC, the cytoplasmic sterility was derived from "IRRI ARC1382", a rice line collected from Assam, India, and the nuclear donor was from the IRRI line lR10179-2-3-1. Finally in O. perennis, the cytoplasmic sterility originated from 0. perennis Acc. 104823, and the nuclear donor was "IR64R" [6-8].

The $\mathrm{R}$ lines possess a fertility restoration gene known as $\mathrm{Rf}$ gene (14). The interaction between the CMS nuclear gene $x$ Rf gene can be classified into two groups of sporopythic (e.g., CMS-WA) or gametophytic (e.g., CMS-BT) 8, 9. Several Rf genes have been identified however Rf1, Rf3, and Rf4 located on chr.s 10, 1, 7, respectively, are the most commercially used restorer genes for hybrid rice production [10-13].

In the two-line system, pollen sterility is induced by environmental conditions such as photoperiod, temperature, or both, which affect the expression of the sterility gene known as Environment-sensitive genic male sterility (EGMS). The primary advantage of the two-line system is that there is no need for a maintainer line, which is required for F1 seed production in the three-line CMS system. This reduces the time and labor of hybrid production. Another important advantage is that any fertile line can be used as a male parent, which greatly increases the flexibility of producing commercial hybrids $[6,14]$.

The EGMS lines are classified into five categories according to which sterility gene(s) they possess; however, only two of them are used for commercial hybrid production: (A) photoperiod-sensitive genic male sterile (PGMS) in which the sterility happens when daylength exceeds more than 13.75 hours (10) and (B) thermo-sensitive genic male sterile (TGMS) in which the sterility occurs when temperature $<30 \mathrm{oC}$ for daytime and $<24 \mathrm{oC}$ for nighttime [1].
The first naturally photoperiod genic male sterile mutant, Nongken58s, was discovered by 1973 in the japonica cultivar "Nongken58". The source of Nongken58s sterility in is a gene pms3 located in chr. 12 , and was detected in a $28.4 \mathrm{~kb}$ fragment via 15 RADP markers [15-18].

Two photoperiod sterile genes, pms1and pms2 located on chr.s 7and 3, respectively, were identified in 32001, a PGMS line derived from Nongken58s. This study showed that the effect of pms1 is greater than pms2 [19]. Two RFLP markers of RG477-RG511, RZ272, are closely linked to pms1 and four RFLP markers, RG191, RG117, RG450, and RG266, are closely linked pms2, [20]. Liu et al. (2001) constructed a contig map including 7 BAC clones and localized pms1 locus in an 85kb DNA fragment that is flanked between two SSR markers, RG477/R277/C67A and R1807 [21]. The pms3 gene was found in two F2 populations of (58S x 1514) and (58s X Lunhui 422). Two RFLP markers, R2708-RZ261, are closely linked pms3 gene 16. A study showed that sterility in a sterile line "Mine $9 \mathrm{~s}$ " is controlled by a recessive PGMS gene, pms4, located on chr.4 [22].

So far, 10 TGMS genes (tms1, tms2, tms3, tms4, tms4, tms5, tms6, tms7, tms 8 and tms-h) have been identified. The tms1 gene was detected on chr. 8, and two RAPD markers, OPB-19, RZ562, and RG978 and an SSR marker, RM 239 are linked to the gene $[23,24]$. The tms 2 gene is located on chr.7 and four SSR markers, RM2, RM10, RM11, and RM214 are tightly linked to the gene [25]. The tms $3(\mathrm{t})$ gene was found on chr.6, and four RADP markers, OPF182600, OPB19750, and OPAA7550, are closely associated with the gene [26]. The tms4 gene was discovered on chr. 2 and four AFLP markers, E2/M5-600, E3/M16-400, E5/M12-600, and E5/M12-200, and one RFLP marker E5/M12-600 are linked to the gene [27]. The Tms 5 gene is found on chr.9 and five SSR marker, RM279, RM492, RM327, RM324, RM257, two AFLP markers, AF10 and AF8, one RAPD marker, RA4, one STS marker, C365-1, and one CAPs marker G227-1 are positionally linked to the gene [28,29]. The tm6(t) gene, detected on chr. 3, was found in a 0A15, a somatic TGMS mutant, and a RADP marker S187-770, and two SSR markers, RM3152 and RM4455 are closely linked to the gene [30,31]. Finally, the tms8 gene was detected in chr.11, and two SSR markers RM21 and RM 24, are tightly linked to the gene [32].

\section{Breeding Methodology}

Commonly, the pedigree-based system is used for the hybrid parental lines. As with the conventional rice breeding program, a single panicle descent, a modification of single seed descent method, is used for development of these lines. Marker assisted selection is used for the identification of desirable plants/progeny. Methods such as single crosses, top-crosses, three-way crosses and backcrosses, test cross, combing ability test can be used for improvement of EGMS, CMS, B, and R lines. Pollen stain is one of the procedures for identification of male sterile plant. In this procedure, 
pollens from a floral are collected and observed by microscope. A sterile pollen appears translucent while a fertile pollen has a dark color. Florals can be classified in 5 groups based on their percentage of sterility/fertility: full sterile where the percentage of sterility is $>100$, sterile (99 to $90 \%$ ), partial sterile (89-71\%) sterile (31$70 \%$ ), fertile (21-30\%), and fully fertile (0-20\%) [33-35].

\section{Male Sterile Seed Production}

Seed increase from male sterile lines is an important factor in hybrid rice parental line development. In the three-line hybrid production, the CMS seeds are produced by crossing the male sterile parent, which serves as a female parent, with its B line, which serves as is designated as the male parent. The pollen abortion in CMS line is due to an interaction between a sterility factor, known as $\mathrm{S}$, located in the mitochondrial DNA and a homozygous recessive allele (rfrf) in the CMS nucleus. The fertility of the B line, despite continuing recessive restorer allele in their nucleus, is by its normal cytoplasm (lack of the $\mathrm{S}$ factor). While a B line has a homozygous rf gene, it has normal mitochondrial, and as a result, the line preserves its fertility, and it can propagate through self-pollination [6].

In the two-line system, the EGMS must meet certain environmental condition to produce seeds. One of the methods of male sterile seed increase is via ratooned selected male sterile plants, where plants are placed in optimum environmental conditions for seed increase (e.g. lower temperature and/or shorter day-length). For mass seed production, seeds from sterile plants are planted in an environment in which the plants meet the desirable photoperiod and/or temperature at their reproductive stage [2,5,36,37].

\section{Hybrid Seed Production}

Hybrid seeds are produced when the female parent (male sterile) is crossed with the male (pollen donor) parent. In the threeline hybrid rice production a CMS line is crossed with a restorer line that has normal cytoplasm and homozygous dominant restorer (RfRf) alleles. In the two-line method, there is no need for developing maintainer line and the EGMS line can be crossed with any rice genotype [38].

There are several essential keys for improving hybrid seed production. Synchronization of flowering between male and female parents is an essential key for an efficient cross pollination. Moreover, the panicle and the stigma exsertion have the important roles for enhancing seed production. Application of gibberellic acid (GA3) can be beneficial for adjusting flowering dates between the male and the female parent and increase the panicle and the stigma exsertion that can significantly increase seed production [39].

\section{Hybrid Rice Seed Quality}

Hybrid rice technology is a technical rice production that aim to develop high yield with good cooking and milling quality $[40,41]$ meet the consumer's expectation. For example, In the U.S. hybrid rice are developed to quality described for "typical southern U.S. cooking quality that is dry and fluffy, long grain, and non-aroma. Therefore, they hybrid rice should have intermediate (21-24\%) amylose content and medium gelatinization temperature (70-74oC) (Chatterjee and Das, 2018, Khus et al. 1979). Amylose content shows volume expansion and degree of flakiness, and sickness [42]. Gelatinization determines time requires for cooking the kernels and Despite yield advantage over than conventional rice cultivars, milling quality of hybrid rice cultivars are low due to amount of chalk. Chalk is considered as an undesirable trait that has decrease rice milling quality. It occurs when loosely packed starch granules cause of formation of air spaces between amyloplasts is due to high nighttime temperature [43]. Further studies are needed to address such issue.

\section{Conclusion}

Food security will one of the important issues in future. Hybrid rice technology is considered an important method for increasing rice production. Developing high-yield and good-quality hybrid rice cultivars requires extensive efforts to developing superior hybrid parental lines as well as innovating new techniques for increasing hybrid seed production. Identification of genes/QTLs associated with agronomic traits and constructing markers related to the desirable characteristics significantly are essential for modern breeding though marker assisted selection. Hybrid rice technology will continue its important role to increase rice production and provide food security for people in the world.

\section{Acknowledgement}

The authors would like to thank Dr. Cassia Oliveira for revising this review paper. The authors would like to express their gratitude to Arkansas rice producers via monies administered by the Arkansas Rice Research and Promotion Board; and the University of Arkansas System Division of Agriculture.

\section{Conflict of Interest}

The authors declare there is no finical interest, or any conflict of interest exists.

\section{References}

1. Virmani SS, Sun ZX, Mou TM, Jauhar AA, Mao CX (2003) Hybrid rice and heterosis breeding. In: Two-line hybrid rice breeding manual Int Rice Res Inst Los Baños, Philippines. p. 1-4.

2. Virmanib SS (2003) Advances in hybrid rice research and development in the tropics in: Virmani SS, et al. [Eds.] Hybrid rice for food security, poverty alleviation, and environmental protection. Proceedings of the 4th International Symposium on Hybrid Rice, Hanoi, Vietnam, Int Rice Res Inst Los Baños, Philippines 7: 20.

3. Ludwig T (2012) From conventional rice to hybrid rice. Impact of hybrid rice on food security: A spatial equilibrium analysis of global adoption and diffusion of hybrid rice varieties. p. 39-60.

4. Walton M (2003) Hybrid rice for mechanized agriculture. In: SS Virmani, et al. [Eds.] Hybrid Rice for Food Security, Poverty Alleviation, and Environmental Protection. Int Rice Res Inst Los Banos, Philippines. pp. 97-102. 
5. Oard J (2018) LSU Agcenter releases new hybrid. In: B Schult, editor Rice Frmin. One Grower Publishing, LLC.

6. Virmani SS, Viraktamath BC, Casal CL, Toledo RS, Lopez MT, et al (1997) Male sterility systems in rice in: Virmani SS, et al. [Eds.] Hybrid rice breeding manual. Int Rice Res Inst Los Baños, Philippines. p: 11-26.

7. Brar DS, Zhu YG, Ahmeh MI, Jachuk PJ, Virmani SS (1996) Diversifying the CMS system to improve the sustainability of hybrid rice technology. In: Virmani SS, et al. [Eds.] Advances in Hybrid Rice Technology, Proceedings of the 3rd International Symposium on Hybrid Rice Hyderabad, India. pp:129-145.

8. Schnable PS, Wise RP (1998) The molecular basis of cytoplasmic male sterility and fertility restoration. Trends in plant science 3(5): 175-180.

9. Guo JX, Liu YG (2012) Molecular Control of Male Reproductive Development and Pollen Fertility in Rice F. Journal of integrative plant biology 54(12): 967-978

10. Yao FY, Xu CG, Yu SB, Li J, Gao YJ, et al. (1997) Mapping and genetic analysis of two fertility restorer loci in the wild-abortive cytoplasmic male sterility system of rice (Oryza sativa L.). Euphytica 98(3): 183-187.

11. Zhang G, Lu Y, Bharaj TS, Virmani SS, Huang N (1997) Mapping of the Rf-3 nuclear fertility-restoring gene for WA cytoplasmic male sterility in rice using RAPD and RFLP markers. Theoretical and applied genetics 94(1): 27-33

12. Wang Z, Zou Y, Li X, Zhang Q, Chen L, et al. (2006) Cytoplasmic male sterility of rice with boro II cytoplasm is caused by a cytotoxic peptide and is restored by two related PPR motif genes via distinct modes of mRNA silencing. The Plant Cell 18(3): 676-687.

13. Akagi H, Nakamura A, Yokozeki Misono Y, Inagaki A, Takahashi H, et al. (2004) Positional cloning of the rice Rf-1 gene, a restorer of BT-type cytoplasmic male sterility that encodes a mitochondria-targeting PPR protein. Theoretical and Applied Genetics 108(8):1449-1457.

14. Virmani SS, Sun ZX, Mou TM, Jauhar AA, Mao CX (2003) Male sterility systems in rice. In: Two-line hybrid rice breeding manual. Int Rice Res Inst Los Baños, Philippines. pp: 5-14.

15. Shi M (1985) The discovery and preliminary studies of the photoperiod-sensitive recessive male-sterile rice (Oryza sativa L. subsp. Japonica) Sci Agric Sin 2: 44-48.

16. Lu Q Li XH, Guo D, Xu CG, Zhang Q (2005) Localization of pms3, a gene for photoperiod-sensitive genic male sterility, to a 28.4-kb DNA fragment. Molecular genetics and genomics 273(6): 507-511.

17. Mei M, Chen L, Zhang Z, Li Z, Xu C, et al. (1999) pms3 is the locus causing the original photoperiod-sensitive male sterility mutation of'Nongken 58S'. Science in China Series C: Life Sciences 42(3): 316-322.

18. Mei MH, Dai XK, Xu CG, Zhang Q (1999) Mapping and genetic analysis of the genes for photoperiod-sensitive genic male sterility in rice using the original mutant Nongken 58S. Crop Science 39(6): 1711-1715.

19. Zhang H, Xu C, He Y, Zong J, Yang X, et al. (2013) Mutation in CSA creates a new photoperiod-sensitive genic male sterile line applicable for hybrid rice seed production. Proceedings of the National Academy of Sciences 110(1): 76-81.

20. Virmani SS, Sun ZX, Mou TM, Jauhar AA, Mao CX (2003) Breeding procedures for developing EGMS lines. In: Two-line hybrid rice breeding manual. Int Rice Res Inst. Los Baños, Philippines p: 23-30.

21. Liu N, Shan Y, Wang F, Xu C, Peng K, et al. (2001) Identification of an 85-kb DNA fragment containing pms1, a locus for photoperiod-sensitive genic male sterility in rice. Molecular Genetics and Genomics 66(2): 271 275.

22. Huang TY, Wang Z, Hu YG, Shi SP, Peng T, et al. (2008) Genetic analysis and primary mapping of pms4, a photoperiod-sensitive genic male sterility gene in rice (Oryza sativa). Rice Science 15(2): 153-156.

23. (2018) Gramene: A comparative resource for plants.
24. Wang B, Xu WW, Wang JZ, Wu W, Zheng HG, et al. (1995) Tagging and mapping the thermo-sensitive genic male-sterile gene in rice (Oryza sativa L) with molecular markers. Theoretical and Applied Genetics 91(67): 1111-1114.

25. Lopez MT, Toojinda T, Vanavichit A, Tragoonrung S (2003) Microsatellite markers flanking the tms 2 gene facilitated tropical TGMS rice line development. Crop science 43(6): 2267-2271.

26. Subudhi P, Borkakati R, Virmani SS, Huang N (1997) Molecular mapping of a thermosensitive genetic male sterility gene in rice using bulked segregant analysis. Genome 40(2): 188-194.

27. Dong NV, Subudhi PK, Luong PN, Quang VD, Quy TD, et al. (2000) Molecular mapping of a rice gene conditioning thermosensitive genic male sterility using AFLP, RFLP and SSR techniques. Theoretical and Applied Genetics 100(5): 727-734.

28. Reddy OU, Siddiq EA, Sarma NP, Ali J, Hussain AJ, et al. (2000) Genetic analysis of temperature-sensitive male sterility in rice. Theoretical and applied genetics 100(5): 794-801.

29. Wang C, Zhang P, Ma Z, Zhang M, Sun G, et al. (2004) Development of a genetic marker linked to a new thermo-sensitive male sterile gene in rice (Oryza sativa L). Euphytica 140(3): 217-222.

30. Ma Z, Wang C, Liu W, Ling D (2002) Somaclonal variation of cytoplasmic male sterile lines with wild rice cytoplasm II, Somaclonal thermo-sensitive genic male sterile mutation. Journal of Tropical and Subtropical Botany 10(4): 313-320.

31. Liu X, Li X, Zhang X, Wang S (2010) Genetic analysis and mapping of a thermosensitive genic male sterility gene, tms $6(t)$, in rice (Oryza sativa L). Genome 53(2): 119-124.

32. Hussain AJ, Ali J, Siddiq EA, Gupta VS, Reddy UK, et al. (2012) Mapping of tms8 gene for temperature-sensitive genic male sterility (TGMS) in rice (Oryza sativa L). Plant breeding 131(1): 42-47.

33. Virmani SS, Viraktamath BC, Casal CL, Toledo RS, Lopez MT, et al. (1997) Organization of hybrid rice breeding program using CMS lines. In: Virmani SS, et al. (Eds.), Hybrid rice breeding manual, Int Rice Res Inst, Los Baños, Philippines p: 11-26

34. Ren G, Gao F, Lu X, Li Z, Liu G, et al. (2009) Development of high-quality cytoplasmic male sterile rice lines for hybrid rice breeding. In: Xie F, et al. (Eds.), Accelerating hybrid rice development. Los Baños (Philippines): International Rice Research Institute pp. 117-130.

35. Pushpam R, Robin S, Manonmani S, Mohana Sundaram K, Raveendran (2009) TS for hybrid rice breeding. In: Xie F, Hardy B (Eds.), Accelerating hybrid rice development, Los Baños (Philippines): International Rice Research Institute, USA. pp. 217-226.

36. Yan ZB, Deren CW, Yan WG (2012) Hybrid Rice Breeding In: RJ Norman et al. (Eds.), BR Wells Arkansas Rice Research Studies 2010, University of Arkansas Agricultural Experiment Station Research Series 600, USA. p. 86-88.

37. Shakiba E, Moldenhauer KAK, Sha X, Counce P, Scott R, et al. (2019) Hybrid Rice Breeding In: RJ Norman, et al. [Eds.] BR Wells Arkansas Rice Research Studies 2018, University of Arkansas Agricultural Experiment Station Research Series 600, USA. p. 87-92.

38. Yuan SC, Zhang ZG, He HH, Zen HL, Lu KY, Et al. (1993) Two photoperiodic-reactions in photoperiod-sensitive genic male-sterile rice. Crop Science 33(4): 651-660.

39. Tiwari DK, Pandey P, Giri SP, Dwivedi JL (2011) Effect of GA3 and other plant growth regulators on hybrid rice seed production. Asian journal of plant sciences 10(2): 133

40. Wilson CE Jr, Moldenhauer K, Cartwright R, Hardke J Rice Cultivars and Seed Production In: 21-29 Hardke J Arkansas rice production handbook. University of Arkansas, Division of Agriculture Cooperative Extension Service, Little Rock, AR p. 21-30. 
41. Jain A, Rao SM, Sethi S, Ramesh A, Tiwari, et al. (2012) Effect of cooking on amylose content of rice. European Journal of Experimental Biology 2(2): 385-388.

42. Lanning SB, Siebenmorgen TJ, Counce PA, Ambardekar AA, Mauromoustakos A (2011) Extreme nighttime air temperatures in 2010 impact rice chalkiness and milling quality. Field Crops Research 124(1): 132-136.
43. Ishimaru T, Horigane AK, Ida M, Iwasawa N, San-oh YA, et al. (2009) Formation of grain chalkiness and changes in water distribution in developing rice caryopses grown under high-temperature stress. Journal of Cereal Science 50(2): 166-174 